\title{
RECENTERING INFORMALITY ON THE RESEARCH AGENDA \\ Grassroots Action, Political Parties, and Democratic Governance
}

\author{
Tina Hilgers \\ McGill University
}

\begin{abstract}
Out of the Shadows: Political Action and the Informal Economy in Latin America. Edited by Patricia Fernández-Kelly and Jon Shefner. University Park: Pennsylvania State University Press, 2006. Pp. 280. $\$ 75.00$ cloth.

Informal Institutions and Democracy: Lessons from Latin America. Edited by Gretchen Helmke and Steven Levitsky. Baltimore: John Hopkins University Press, 2006. Pp. 351. \$25.00 paper.

Patrons, Clients, and Policies: Patterns of Democratic Accountability and Political Competition. Edited by Herbert Kitschelt and Steven J. Wilkinson. New York: Cambridge University Press, 2007. Pp. 377. $\$ 96.00$ cloth.
\end{abstract}

The three volumes reviewed here aim to bring informality to the center of the Latin American (and, for Kitschelt and Wilkinson, the broader) research agenda, pointing to the inextricable linkages between informality and the formal activities and structures of the state. They also identify the positive effects of informal activities, which have often been regarded as pernicious. Out of the Shadows uses the new economic sociology to show how informal economies are embedded in social structures. It also highlights the role of the state in generating informal economic and political activities at the grassroots level through exclusionary politics and policy. Informal Institutions and Democracy expands the scope of the new institutionalism, investigating the contingencies between formal and informal institutions, and revealing the real workings of democracy in Latin America. Patrons, Clients, and Policies employs an offshoot of political opportunity structures to uncover the effects of development, political competition, and ethnocultural mobilization on clientelist and programmatic citizen-politician links.

The schools of research favored in these books complement one another in that all contain actor-centered elements but focus on different 
contextual factors as crucial to explain action. As a result, they generate different types of information that, when taken together, present a more comprehensive vision of Latin America than any one type of data could do alone. In addition, these works draw attention to informality where it has sometimes been ignored; demonstrate that informality has both positive and negative effects for participants and the frameworks alongside which it exists; and show that, where there is widespread informality, imported laws and institutions do not have the desired result of copying "northwestern" legal-institutional processes.

\section{DEFINING THE INFORMAL}

The literature on informality is broad but diffuse. In the 1950s and 1960s, researchers studying developing countries discovered the importance of kinship, friendship, and patronage structures within political, economic, and social interactions. These structures were often explained functionally: where formal laws for regulating interactions did not exist, some basis for managing relations between individuals was necessary. To coexist, survive, and trade, individuals had to develop trust. ${ }^{1}$ This initially inclusive approach to the study of informality soon broke apart, as social scientists began to concentrate on their particular fields of interestculture, economy, politics, and so on-and then as political scientists lost interest. Sociologists and anthropologists continued to turn out excellent work on informality, but with a tendency to look at either political or economic dimensions, while political scientists largely turned to analyses of the state and its institutions or to new social movements that ostensibly opposed and remained independent of the state. ${ }^{2}$

As is argued cogently in the introductory essays of the three books reviewed here, much excellent work has been done, but our understanding of politics and economics in Latin America (and beyond) is suffering from the exclusion of informality as a key analytical factor. More than ten years ago, Guillermo O'Donnell wrote that "[p]articularism [informal exchange] is a permanent feature of human society; only recently, and only in some places and institutional sites, has it been tempered by universalistic norms and rules." ${ }^{3}$ Recognizing this, the volumes reviewed

1. See, for example, Sidney W. Mintz and Eric R. Wolf, "An Analysis of Ritual CoParenthood (Compadrazgo)," Southwestern Journal of Anthropology 6, no. 4 (1950): 341-368; and Carl H. Landé, "Networks and Groups in Southeast Asia: Some Observations on the Group Theory of Politics," American Political Science Review 67, no. 1 (1973): 103-127.

2. One researcher who has consistently considered the political, social, and economic aspects of informality is Judith Adler Hellman. See "The Role of Ideology in Peasant Politics: Peasant Mobilization and Demobilization in the Laguna Region," Journal of Interamerican Studies and World Affairs 25, no. 1 (1983): 3-29, and Mexican Lives (New York: New Press, 1994).

3. Guillermo O'Donnell, "Another Institutionalization: Latin America and Elsewhere," Kellogg Institute for International Studies at the University of Notre Dame Working Paper \#222 (March 1996), 15. 


\section{Latin American Research Review}

here make the case that informal aspects should be brought into existing frameworks and that commonly accepted models and representations should be changed.

In keeping with these principles, in Fernández-Kelly and Shefner, the informal economy is defined as economic activities that are not actively regulated by the state, or that escape such regulation, functioning instead according to their own rules of trust and reciprocity $(1,8)$. Helmke and Levitsky similarly identify informal institutions as "socially shared rules, usually unwritten, that are created, communicated, and enforced outside officially sanctioned channels" (5). Kitschelt and Wilkinson study variants of party competition, focusing on a particular type of informal politics: clientelism. They describe clientelism as reciprocal, discretional, and contingent exchanges of goods and services between politicians and citizens, and view more democratic and programmatic links as policy-based competition among parties that target particular electoral constituencies. The success of both these linkages depends in part on mutual expectations, which repetition and learned behavior strengthen. All three collections essentially view informality as a set of extralegal activities governed by unwritten rules and sanctions known to the affected segment of the population.

\section{DIFFERENT PERSPECTIVES, COMPLEMENTARY DATA}

Each book endeavors to draw attention to the research school its authors consider most apt for explaining informality. Although all three approaches contain actor-based elements, their premises are not the same. New economic sociology insists that economic activity is embedded in social norms and traditions; new institutionalism finds that the rules and institutions of politics shape actors' choices; and political opportunity structure looks to economic, historical, and institutional factors as causes for action. Given these premises, the three books take different levels of political reality as their points of departure: Fernández-Kelly and Shefner focus on grassroots phenomena; Helmke and Levitsky, on institutions and state-level analyses; Kitschelt and Wilkinson, on the intersection of the preceding two interests. Researchers of Latin American politics and society will benefit from the comprehensive view gained from reading all three books together.

The new economic sociology found in Out of the Shadows is a response to rational-actor models, which assume that self-interest and goal orientation inform behavior. Sociologists of this school recognize the importance of economic stimuli in sociopolitical structures and action, but argue that economic behavior is meaningless in abstraction from the social networks, institutions, and hierarchies that shape our understand- 
ings of appropriate behavior. ${ }^{4}$ While Fernández-Kelly and Shefner follow this approach, their volume does not directly grapple with it until Cross and Peña briefly explain the school in the third chapter, thus missing an opportunity to advance the new economic sociology by situating themselves within its internal debates. Nonetheless, the individual contributions of their volume are excellent, and add many data that support the notion of economic action's embeddedness in social relations. For example, Cross and Peña show how the informal economic activities of street vendors in Mexico City and the illegal economic activities of crack sellers in New York City are able to function only because organizations, roles, and dispute-resolving mechanisms create enough trust among actors to outweigh the risks they incur. ${ }^{5}$ Itzigsohn points to socially generated trust and cooperation as crucial to the success that grassroots economic communities in Costa Rica, Ecuador, Brazil, and Guatemala (among others) have had in linking themselves to global networks. Auyero finds that socially learned, collective understandings of political processes and protest underlie the explosion of grassroots responses to exclusionary economic policies.

It might have been helpful to structure Out of the Shadows more clearly around this idea of embeddedness. Instead, the strength of Out of the Shadows lies in the linkage between both national political processes and policies and between grassroots informality. González de la Rocha's research on urban household economies in Mexico shows that the survival of poor people depends on informal activities-producing petty commodities for trade and consumption and passing goods and services through networks of reciprocal exchange-that require resources emanating from the formal sector. Goods can only be produced, and networks established, with materials and assets generated from employment income or access to social programs. However, neoliberal structural adjustment has led to lost jobs and state retrenchment, generating a shift from "resources in poverty" to a "poverty of resources" (98). Itzigsohn adds that neoliberal policies are "anti-market" (82). Although these allow large corporations to thrive, they block the networks of trust essential to the success of small businesses and informal entrepreneurship. Similar arguments pertain to informal political action. Shefner argues that the poor's shrinking resource base is closely linked to a decrease in nonelectoral political participation. The more difficult is the struggle to survive, the less time the poor have to be active in their communities. Gay, Ramírez Sáiz, and Shefner all point to a disturbing connection between market reform and democratization. De-

4. Frank Dobbin, The New Economic Sociology (Princeton, NJ: Princeton University Press, 2004).

5. Illegal activities are a special category, distinct from informality, as Cross and Peña (60-61) and Centeno and Portes (27) discuss. 


\section{Latin American Research Review}

mocracy has, perversely, demobilized the masses, whose demands for political rights have ostensibly been met with democracy, even as their living situation deteriorates and politicians do not offer real policy alternatives. On the whole, the contributions to Out of the Shadows are persuasively argued and provide excellent empirical material on grassroots informal activities across Latin America.

Helmke and Levitsky elaborate a clearer theoretical framework than do Fernández-Kelly and Shefner largely because one of their objectives is to reorient the new institutionalism. Since the early 1980s, an increasing number of political scientists have turned toward institutionalism, arguing that the way in which representative, executive, bureaucratic, judicial, social, and economic organs and regulations are structured has important effects on political choices, actions, and outcomes. These scholars have focused mainly on written regulations of political organization and interaction enforced by the state-formal institutions. However, Helmke and Levitsky argue that Latin American politics is marked by four types of informal rules: (1) those that converge with effective formal rules and are "complementary," (2) those that diverge from effective formal rules and are "accommodating," (3) those that converge with ineffective formal rules and are "substitutive," (4) and those that diverge from ineffective formal rules and are "competing" (13-16). Only analyses accounting for these interactions render a true account of how Latin American democracies function because, they say, "political actors respond to a mix of formal and informal incentives" (2). The contributors to their volume situate themselves vis-à-vis this introductory framework.

In an excellent chapter on Chilean democracy, Siavelis explains why posttransitional politics in this country have been stable and democratic despite formal institutional obstacles. In a multiparty presidential system with a weak legislature, presidents should tend to overuse their powers, eventually leading to democratic breakdowns. However, the threat of return to military rule convinced elite political actors to cooperate. Understanding the problems of their formal institutions, they constructed four accommodating informal institutions: a lasting coalition among left-wing parties that has governed Chile since the transition, a quota system to distribute appointed positions among the partners of this coalition, informal negotiations to gather support for policy initiatives, and "election insurance" (analyzed in a later chapter by Carey and Siavelis) to reward losing candidates in the binomial system. These informal rules are understood by the participants, who can enforce the deals using mechanisms such as the threat or reality of support withdrawal.

Mejía Acosta describes secret and informal legislative-executive agreements, or "ghost coalitions," as complementary informal institutions that create governability in Ecuador despite formal and institutional incentives for legislative stalemate. Langston analyzes the Mexican tradition of presi- 
dents choosing their own successors to maintain stability in the dominant Partido Revolucionario Institucional (PRI) — an informal institution that comes closer to underpinning formal ones than to competing with them-while Eisenstadt treats agreements between this hegemonic party and the conservative opposition on compensation for accepting fraudulent electoral processes, a substitutive informal institution. The strength of these and several other contributions to Helmke and Levitsky's volume lies in their detailed descriptions of the processes at work. They go beyond the editors' introductory theoretical framework to give important insights into politics on the ground.

The theoretical orientation of Informal Institutions and Democracy does limit it in certain foreseeable ways. The application of the rationalist variant of new institutionalism and the focus of all but a few contributors on the state means that the grassroots informality mentioned in the introduction (18) is largely bypassed in favor of more elite-driven informal institutions. The reasons identified for the emergence of informal institutions are primarily actor based. Actors create informal rules (1) whereby formal institutions are incomplete and guidelines for solving problems are necessary; (2) whereby it is less costly to experiment with informal institutions than to attempt formal institutional change; (3) whereby formal institutions are weak, unrealistic, or just not enforced; and (4) whereby the goals actors wish to attain are not formally acceptable or are illegal (19-20). This market-based, functionalist view of rules development means that in the essays that consider grassroots phenomena (clientelism in TaylorRobinson and in Desposato, informal justice systems in Van Cott, and unpunished killings by police in Brinks), they are portrayed in a more mechanical fashion than in Out of the Shadows, providing little insight into the meaning of informality in the daily lives of participants.

In Patrons, Clients, and Policies, Kitschelt and Wilkinson argue that the "responsible-party model" (1-2) for party competition explains only those voter-politician (principal-agent) links in which citizens judge and politicians strategize on the basis of programmatic issues. This model does not deal with the patronage-based linkages that exist in many developing (and developed) economies, in which accountability and responsiveness do not work according to impersonal policy criteria. To fill this gap, Kitschelt and Wilkinson construct a new model using ideas from political opportunity structures theory, which Kitschelt elsewhere describes as "specific configurations of resources, institutional arrangements and historical precedents for social mobilization, which facilitate the development of protest movements in some instances and constrain them in others." 6 The editors suggest that such configurations also exist for ac-

6. Herbert Kitschelt, "Political Opportunity Structures and Political Protest: Anti-Nuclear Movements in Four Democracies," British Journal of Political Science 16, no. 1 (1986): 58. 


\section{Latin American Research Review}

countability and can explain variations in principal-agent links. They argue that rational individuals act strategically within a set of constraints generated by economic, institutional, and ethnocultural elements. In contexts of advanced economic development, strong institutional promotion of democratic electoral competition and impartial economic management, as well as a relatively ethnoculturally homogenous population, links are likely to be programmatic. Voters perceive that long-term policy benefits are more valuable than short-term clientelist benefits, and politicians believe that rising resource costs per vote make clientelism unfeasible. Where economic and institutional elements are weak and the population is ethnoculturally heterogeneous, voters want or need a guaranteed immediate benefit, the vote is cheap, and links are likely to be clientelist.

The cross-pollination from social movement theory to party competition is innovative, and Kitschelt and Wilkinson develop a process of complex causality applicable to a variety of cases. They argue that (1) strong electoral institutions increase political competition, leading parties to back closer accountability between politicians and citizens; (2) the degree of economic development-market sophistication, citizen affluence, education-affects whether these links will be programmatic, clientelist, or mixed; (3) weak economic institutions - regulations for subsidies, licenses, public contracts, and the environment-facilitate discretional resource allocation and politicization of the economy (i.e., clientelism); (4) highly politicized economies slow economic development and electoral competition, as constituents support the politicians who protect their economic interests; (5) although ethnocultural mobilization may preexist, it may be caused by development and weaken the economy; and (6) in ethnoculturally divided societies, people try to protect themselves from perceived favoritism toward other groups by creating personal networks within their own group, undermining impartial institutions, and politicizing the economy. The numerous combinations of, and contingencies among, these causal factors require extensive investigation to determine how they are at work in individual cases. Patrons, Clients, and Policies thus forms part of the expanding nexus between structure and agency, relinquishing a degree of rational choice parsimony for greater explanatory power.

The key element of Kitschelt and Wilkinson's model—the quality of economic and democratic development-is crucial to understanding clientelism. Thus, the contributors make a series of arguments leading to the conclusion that economic growth and transition to electoral democracy do not inevitably bring a shift from clientelist to programmatic politics. Rather, the wealth resulting from economic growth has to be redistributed through depoliticized institutions to provide basic resources broadly. In addition, education levels have to rise so that voters attain the cognitive capacity to weigh the immediate benefits of clientelism against the longterm benefits of progressive policy. 
In keeping with these arguments, Levitsky's essay in Patrons, Clients, and Policies explains the increase of clientelism with market liberalization in Latin America. He argues that the political parties that were able to survive the economic crises, policy change, and decline of the industrial working class in the 1980s and 1990s did so by shifting from labor to machine politics. Patronage machines enabled parties to engage in the market reform demanded by certain domestic and international actors while delivering the goods and services demanded by other sectors through clientelist networks. Market liberalization slashed big bureaucracies and state-run economies, but clientelism survives under politicized bureaucracies and weak rule of law.

To come to a similar conclusion, Magaloni, Diaz-Cayeros, and Estévez use quantitative modeling to show how the PRI used the Programa Nacional de Solidaridad to minimize electoral risk by targeting goods to certain constituencies. In a piece on Brazil, Lyne constructs a theory of the "voter's dilemma" (159) to suggest that only those voters who choose clientelist candidates insure themselves against exclusion from goods distribution should their candidate be defeated, guaranteeing the continuity of clientelism until voters are wealthy enough to disregard the effect of free riding. Medina and Stokes use examples from Argentina, Colombia, Italy, and the United States to bring life to a game theory model in which patrons monopolize goods and monitor the electoral activities of voters. Significantly, they show that clientelism does not require perfect monitoring capacity, but simply the perception by voters that such capacity exists and affects the distribution of benefits. As in Informal Institutions and Democracy, none of the contributors to Patrons, Clients, and Policies (with the exception of Krishna) conveys the day-to-day climate of clientelism. Kitschelt and Wilkinson attempt to bring elements of tradition and community into their explanation, but they, and many of the authors in their collection, deal too abstractly with such factors to provide an understanding of clientelism beyond its definitional characteristics.

\section{COMMON THEMES ON INFORMALITY}

Separately and as a group, the three books make an important contribution to the literature. They bring informality back to the center of the research agenda, examining it in daily life at the grassroots level, in the interaction between the strategies of voters and politicians in political parties, and in the mechanisms of governance. This focus is particularly important to political science, where informality has been marginalized. The books also dispel a series of myths about the negative effects of informality on politics, the economy, and the social fabric. Finally, they demonstrate why legal-institutional models from advanced capitalist, stable democracies cannot bring those countries' processes to Latin America. 


\section{Latin American Research Review}

Informal Institutions and Democracy most clearly addresses the positive and negative effects of informality, because, as the title suggests, it is the editors' express goal to evaluate the impact of informal institutions on democracy. Thus, as Desposato argues in his essay on Brazil, political representation may be impeded where extensive clientelism renders parties less likely to generate cohesive policy platforms and push for democratic progress; yet, as Taylor-Robinson notes in her chapter on Honduras, without clientelism local interests might not be represented at all. Langston's piece on the dedazo in Mexico shows that some politicians keep rules informal to skirt democratic accountability, whereas Eisenstadt's work on postelectoral concertacesiones in Mexico demonstrates that others use them to increase accountability. Siavelis and Mejía Acosta argue in their chapters that informal coalitions and negotiations can enhance democratic governability, although they may also decrease accountability and transparency. Similarly, Van Cott contends that informal arrangements can at times enhance the rule of law, but Brinks shows that they may jeopardize it at others.

Patrons, Clients, and Policies is more circumspect on this issue, not stating the positive possibilities (or at least the harmlessness) of clientelism clearly until the conclusion. Of course, the linkages at issue in Informal Institutions and Democracy may more readily be defined as benign, because many of them have been elaborated precisely to make otherwise intractable formal rules democratically functional. Clientelism, however, more closely resembles the broader, grassroots institutions that Helmke and Levitsky consider difficult to change and that O'Donnell describes as a "deep sea" into which formal democratic institutions are plunged (in Helmke and Levitsky, 289). Nonetheless, Kitschelt and Wilkinson conclude on a number of important points. They argue that, in a context of political competition, clientelist resource distribution may not be worse than programmatic redistribution. For example, in highly fragmented party systems with programmatic competition, politicians still target benefits to specific constituencies. Among advanced democracies, and among less developed ones, inequality is not greater in clientelist than in nonclientelist countries. In peripheral regions, clientelist benefits are often the only thing poor people can get from politicians. Finally, some clientelist policies (e.g., export subsidies, tariff protection, funding at low interest rates) can boost economic growth where there are low levels of development.

In Out of the Shadows, the positive sides of informality are more forcefully apparent than in the other two volumes. The contributors deal with poor people marginalized by exclusionary political structures and economic policies and, therefore, focus on the necessity of informal mechanisms in the struggle to survive. Petty commodity production in the home (de la Rocha), street vending (Cross and Peña), popular protest (Auyero), and voting in exchange for resources (Gay) are indispensable activities 
for the poor and therefore are not to be judged lightly. Only Centeno and Portes clearly articulate a long-term, negative impact of informality. They explain that informal economic regulatory systems (i.e., social networks) may be functional in the immediate term for the actors involved but are dysfunctional in the long term because a modern, industrial economy is too complicated to operate through social networks of trust.

That foreign regulatory and institutional models do not work when imported to countries with different histories and traditions is not a central thesis of any of the three books. Yet their subject matter necessarily leads the authors to question what might be wrong with the formal that makes the informal so important. In Out of the Shadows, Cross and Peña point out that, although "officials in Mexico negotiate with organizations representing vendors, they consistently plan as if those organizations did not exist, or in ways that attempt to minimize their power" (73), because they copy legal systems from countries that do not have significant informal economies. In an afterword to Informal Institutions and Democracy, O'Donnell argues that the formal rules and institutions of democracy grafted onto Latin American reality have failed to import democratic behavior. He suggests that, if we wish to be more successful in strengthening democracy, we must carefully study the behavior that results from "common knowledge" rules (286) and puzzle out when and why individuals shift from these to those of formal institutions. Given Kitschelt and Wilkinson's model of party competition, which intertwines electoral competition with economic development and other elements, both they and their contributors implicitly address the success of imported models: democratic elections and similar institutions cannot create democratic behavior so long as economic development is uneven and unequal, or where ethnocultural mobilization is extensive.

As previously mentioned, it would be most helpful to read these three volumes together, as each presents a different type of material on informality. However, I would note that they may appeal and be useful to different audiences. Patrons, Clients, and Policies is not always as accessible as the others, so I would recommend it to advanced graduate students and specialists only, whereas the other two books are appropriate for a wider public. Informal Institutions and Democracy will interest students and specialists studying institutionalist theories and Latin American democracy. Out of the Shadows should be a central reference for those interested in the grassroots reality of neoliberalism and democracy, and its chapter by Centeno and Portes should be read by anyone interested in Latin American economies. Overall, there is still a need for more integrated studies of informality in which researchers puzzle out how processes at different levels relate to one another. 